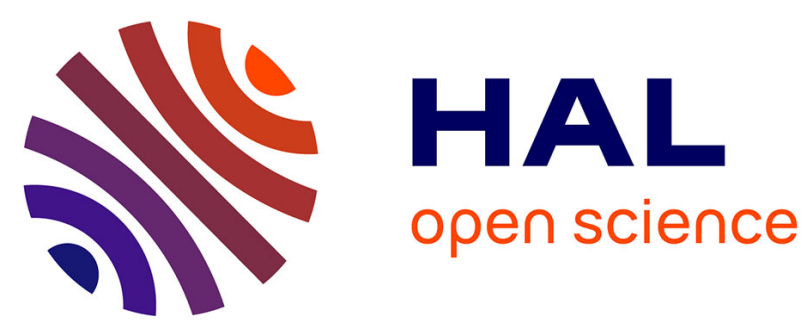

\title{
Fast switch from extensional exhumation to thrusting of the Ronda Peridotites (South Spain)
}

Gianluca Frasca, Frédéric Gueydan, Marc Poujol, Fleurice Parat, Patrick Monie, Alexandre Pichat, Sophie Mazier, Jean-Pierre Brun

\section{- To cite this version:}

Gianluca Frasca, Frédéric Gueydan, Marc Poujol, Fleurice Parat, Patrick Monie, et al.. Fast switch from extensional exhumation to thrusting of the Ronda Peridotites (South Spain). Terra Nova, 2017, 29 (2), pp.117-126. 10.1111/ter.12255 . insu-01441962

\section{HAL Id: insu-01441962 \\ https://hal-insu.archives-ouvertes.fr/insu-01441962}

Submitted on 20 Jan 2017

HAL is a multi-disciplinary open access archive for the deposit and dissemination of scientific research documents, whether they are published or not. The documents may come from teaching and research institutions in France or abroad, or from public or private research centers.
L'archive ouverte pluridisciplinaire HAL, est destinée au dépôt et à la diffusion de documents scientifiques de niveau recherche, publiés ou non, émanant des établissements d'enseignement et de recherche français ou étrangers, des laboratoires publics ou privés. 
DR. GIANLUCA FRASCA (Orcid ID : 0000-0003-1038-2375)

Received Date : 20-Jan-2016

Revised Date : 26-Nov-2016

Accepted Date : 11-Jan-2017

Article type : Paper

\section{Fast switch from extensional exhumation to thrusting of}

\section{the Ronda Peridotites (South Spain)}

Gianluca Frasca ${ }^{1,2}$, Frédéric Gueydan', Marc Poujol' ${ }^{1}$, Jean-Pierre Brun ${ }^{1}$, Fleurice Parat $^{2}$, Patrick Monié ${ }^{2}$, Alexandre Pichat ${ }^{2}$, and Sophie Mazier ${ }^{1}$

${ }^{1}$ Géosciences Rennes, UMR 6118 CNRS/INSU, OSUR, Université Rennes 1, 35042 Rennes Cedex, France

${ }^{2}$ Géosciences Montpellier, Université Montpellier, UMR 5243 CNRS/INSU, Place E. Bataillon, CC60, 34093 Montpellier Cedex, France

*Corresponding author e-mail: gianluca.frasca@univ-rennes1.fr;

This article has been accepted for publication and undergone full peer review but has not been through the copyediting, typesetting, pagination and proofreading process, which may lead to differences between this version and the Version of Record. Please cite this article as doi: $10.1111 /$ ter. 12255

This article is protected by copyright. All rights reserved. 


\section{ABSTRACT}

The Alboran Domain, situated at the western end of the Mediterranean subduction system, is characterized by the Ronda Peridotites, one of the world's largest exposures of sub-continental mantle. Using U-Pb (LA-ICP-MS) and Ar-Ar dating, we precisely dated two tectonic events associated with the Tertiary exhumation of the Ronda Peridotites. First, shearing along the Crust-Mantle Extensional Shear Zone caused, at ca. 22.5 Ma, mantle exhumation, local partial melting in the deep crust and coeval cooling in the upper crust. Second, the Ronda Peridotites Thrust triggered the final emplacement of the peridotites onto the continental crust at ca. $21 \mathrm{Ma}$, as testified by granitic intrusions in the thrust hanging-wall. The tectonic evolution of the western Alboran Domain is therefore characterized by a fast switch from continental lithospheric extension in a backarc setting, with sub-continental mantle exhumation, to a rift inversion by thrusting driven by shortening of the upper plate.

\section{INTRODUCTION}

The Mediterranean is characterized by the coexistence of backarc basins and arcuate subduction zones caused by slab rollback (e.g., Calabria, Hellenic trench; Wortel and Spakman, 2000). The Gibraltar arc (Betics in Spain and Rif in Morocco) is marked by the exhumation of large bodies of sub-continental mantle, the Ronda Peridotites, whose role in the geodynamics of the western Mediterranean is still debated (Garrido et al., 2011; Van Hinsbergen et al., 2014). The polycyclic history of the Ronda lithospheric section makes it difficult to unequivocally link slab rollback evolution and sub-continental mantle exhumation, as proposed for the central Mediterranean backarc system (Acosta-Vigil et al., 2016; Sánchez-Rodríguez and Gebauer, 2000; Bache et al., 2010).

The Ronda Peridotites consist of a tectonic sliver within the Alboran crust, bounded by two major tectonic contacts. A Crust-Mantle Extensional Shear Zone at the top of the 
Ronda Peridotites accommodated extreme continental lithospheric thinning (CMESZ, red in Fig. 1; Afiri et al., 2011; Argles et al., 1999; Frasca et al., 2016; Précigout et al., 2013). The crustal rocks overlying the peridotites comprise a strongly attenuated crustal section (Balanyá et al., 1997). The metamorphic grade decreases continuously from granulite facies to unmetamorphosed rocks in the $4 \mathrm{~km}$ thick crustal sequence above the Ronda Peridotites (Argles et al., 1999; Balanyá et al., 1997; Barich et al., 2014). Furthermore, shearing in the granulites was coeval and consistent with garnet-spinel mylonitization at the top of the mantle (Précigout et al., 2013; Frasca et al., 2016). However, the age of this continental lithospheric thinning is still debated. In the granulites, garnet rims and part of the matrix crystallized during the Tertiary (Massonne, 2014; Platt et al., 2003b; Whitehouse and Platt, 2003). A much older partial melting event has been proposed from ca. 1.4-1.2 GPa to 0.6-0.5 GPa at around $800^{\circ} \mathrm{C}$ for part of the Ronda crustal section in Hercynian times (Barich et al., 2014; Ruiz Cruz and Sanz de Galdeano, 2014). Furthermore, Jurassic ages have been obtained in pyroxenite layers within the peridotites (Sanchez-Rodriguez and Gebauer, 1999).

The Ronda Peridotites Thrust (RPT, blue in Fig. 1; Frasca et al., 2015; Vitale et al., 2014) marks the second tectonic contact of the peridotites. The rocks below the Ronda Peridotites are highly diverse, with variable degrees of metamorphism from low-grade limestones to strongly mylonitized marbles (see summary in Frasca et al. (2015)). Migmatites in the footwall and granitic dikes intruding the mantle and the crustal hanging wall yield a cluster of crystallization ages between 23 and 19 Ma (Monié et al., 1994; Sosson et al., 1998; Sánchez-Rodríguez and Gebauer, 2000, Esteban et al., 2011; Rossetti et al., 2010). A thermal overprint on Hercynian migmatites in the thrust footwall during the Tertiary has been also reported (Acosta-Vigil et al., 2014). A major shortening event during the Miocene therefore triggered the final crustal emplacement of the Ronda Peridotites (Tubía et al., 1997; Précigout et al., 2013).

This article is protected by copyright. All rights reserved. 
These first order geological features have yielded a diversity of tectonic models for the exhumation of the Ronda Peridotites from mantle depths to the surface. The three main models are: 1/ exhumation during the Hercynian orogeny (collision/collapse) with only passive reworking during the Alpine orogeny (Massonne, 2014; Ruiz Cruz and Sanz de Galdeano, 2014); 2/ exhumation during the Tethysian rifting, followed by the subduction of the Tethyan passive margin (and its lithospheric mantle) during the complex Alpine phase (Tubía et al., 1997; Vissers et al., 1993); and 3/ Oligo-Miocene exhumation during westward Alboran slab roll-back, followed by rift-inversion during the lower Miocene (Garrido et al., 2011; Gueydan et al., 2015; Précigout et al., 2013).

In order to discriminate between these models, we provide new ages (U-Pb LA-ICPMS and Ar-Ar) obtained on syndeformational structures related to both thinning and thrusting. The ages clearly separate two successive crustal melting events structurally associated with the Ronda Peridotites. We compare the new ages with the available datasets in the region and discuss their geodynamic implications.

\section{TWO SUCCESSIVE CRUSTAL MELTING EVENTS}

\section{Structural setting}

Two types of intrusion were sampled from the Ronda Peridotites and their crustal envelope (for positions of the samples, see the regional map and the $\mathrm{N}-\mathrm{S}$ cross-section in Fig. 1A,C and a more precise structural location on the schema in Fig. 2A): 1- a syndeformational melt vein in the deepest part of the crust overlying the peridotites, in the

Crust-Mantle Extensional Shear Zone (GF13-7; Figs. 2B,C,D); and 2- four leucocratic dikes crosscutting the main foliations either of the Ronda Peridotites or of the overlying deep crust (GF13-6, GF13-9, GF13-10 and GF13-5a) (Figs. 2G,H,I). 
The syn-deformational intrusions (e.g. GF 13-7) are structurally associated with a topto-the-W shearing along the Crust-Mantle Extensional Shear Zone (Frasca et al., 2016; Précigout et al., 2013). Syn-deformational intrusions are located either in veins that rotated during shearing (Fig. 2B) or along $\mathrm{C}^{\prime}$-type shear bands in the high-temperature granulitic foliation (Fig. 2C). $\mathrm{C}^{\prime}$-type shear bands are slightly oblique to the regional high-temperature foliation, while veins cut the foliation at higher angles (see stereoplots in Figs. 2E,F).

In contrast, the undeformed dikes intruding the Ronda Peridotites and the crustal envelope (GF 13-5a, GF13-6, GF 13-9 and GF 13-10) crosscut the regional foliation (Figs. $2 \mathrm{G}, \mathrm{H}$ ) and show a random distribution in the stereographic projection (Fig. 2L). These dikes are therefore unrelated to the high-temperature foliations (stereoplot in Fig. 2L) and their source is structurally identified below the Ronda Peridotites (Fig. 2A). This second type of intrusion was thus emplaced during the motion of the Ronda Peridotite Thrust.

\section{Petrography and geochemistry}

A magmatic origin for the syn-deformational and undeformed sampled intrusions is clearly indicated by interlocking, graphic and granophyric textures (Figs. 2D,I; see also Cuevas et al. (2006) and Barich et al. (2014)). U-Pb LA-ICP-MS dating and Nd and Sr isotope analyses were performed at Géosciences Rennes following the procedures described in Ballouard et al. (2015) (see Tables DR $1^{1}$ and DR2 ${ }^{1}$ for details and operating conditions of the LA-ICP-MS measurements ${ }^{1}$ ).

The isotopic signature of the dikes is similar to those of other Alboran Domain granites (Rossetti et al. (2013) and references therein). The high ${ }^{87} \mathrm{Sr} /{ }^{86} \mathrm{Sr}(0.715037$, GF13-9, and 0.718605, GF13-7) and the low ${ }^{143} \mathrm{Nd} /{ }^{144} \mathrm{Nd}(0.512020$, GF13-9, and 0.512026, GF13-7) values indicate a predominantly crustal origin for both types of dikes, compatible with dehydration melting of a metasedimentary source (Table 1). However, the different structural 
contexts (Fig. 2A) and the large differences in their rare earth element geochemistry (REE, Fig. 3A) suggest different timings and different sources for the melt, as supported by their respective TDM (i.e. Time Depleted Mantle model age) values of 1270 and 2600 Ma (Tables $\mathrm{DR} 3^{1}$ and DR5 $\left.{ }^{1}\right)$.

\section{In situ melting in the lower crust above the peridotites at ca. $22.5 \mathrm{Ma}$}

The syn-deformational intrusion in a shear zone located inside the granulites (GF13-7) is peraluminous, mainly composed of $\mathrm{K}$-feldspar, quartz and plagioclase, with accessory tourmaline, and presents a concave REE pattern (Fig. 3A). This enrichment in heavy REE suggests that garnet was consumed in the melting reaction (Fig. 3A and Table 1).

Cathodoluminescence (CL) images of the zircon grains (Fig. 3B insets) show distinct cores and rims for some of them, although, when euhedral, the grains are fairly homogeneous. The cores yield dates ranging from Neoarchaean to Cretaceous (Table DR $3^{1}$ ) in good agreement with the TDM value for this sample (Table DR $3^{1}$ ). The rims and the homogeneous grains give consistent Miocene dates. In a Tera-Wasserburg diagram, these analyses plot in a concordant to sub-concordant position (Fig. 3B). The concordant data yield a concordia age of $22.52 \pm 0.16 \mathrm{Ma}(\mathrm{MSWD}=1.4, n=16)$, consistent with a mean ${ }^{206} \mathrm{~Pb} /{ }^{238} \mathrm{U}$ age of $22.52 \pm 0.18$ $(\mathrm{MSWD}=1.6, n=20)$.

\section{Undeformed dikes: Melt extraction from the metamorphic sole below the Ronda}

\section{Peridotites at ca. $20 \mathrm{Ma}$}

Undeformed dikes intruding the peridotites and the overlying crustal rocks (GF13-6, GF13-5A) have a chondrite-normalized REE pattern enriched in light REE and depleted in heavy REE compared with the extensional-related sample (GF 13-7), suggesting a lower 
degree of partial melting and different sources (Fig. 3A). Our samples GF13-6 and GF13-5a present REE patterns similar to those of Rossetti et al. (2013) from the Rif (Fig. 3A). These rocks also contain slightly more plagioclase and biotite than sample GF13-7, and often titanite.

The dike from which GF13-5a was sampled crosscuts the granulite foliation. Of the zircon grains studied from this sample, three inherited cores give a Palaeozoic date of 337.2 $\pm 0.13 \mathrm{Ma}(\mathrm{MSWD}=0.21)$ (Table $\left.\mathrm{DR} 4^{1}\right)$, while the remaining 15 data points are concordant (Fig. 3C) and yield a concordia age of 20.66 $\pm 0.13 \mathrm{Ma}(\mathrm{MSWD}=1.06 ; n=15)$ with a mean ${ }^{206} \mathrm{~Pb} /{ }^{238} \mathrm{U}$ age of $20.65 \pm 0.13 \mathrm{Ma}(\mathrm{MSWD}=0.17 ; n=15)$ (Table DR4 $\left.{ }^{1}\right)$. The inherited components are far less abundant than in the extensional-related sample GF13-7 and indicate a different origin, suggesting two distinct partial melting events.

Samples GF13-9 and GF13-10 consistently show inherited components similar to sample GF13-5a, suggesting a different origin from sample GF13-7. In sample GF13-9, analyses plot in a concordant to discordant position depending on the degree of $\mathrm{Pb}$ loss and/or the presence of common $\mathrm{Pb}$ (Fig. 3D). A group of 10 concordant analyses yield a concordia age of $19.98 \pm 0.27 \mathrm{Ma}(\mathrm{MSWD}=2.2 ; n=10)$ and a mean ${ }^{206} \mathrm{~Pb} /{ }^{238} \mathrm{U}$ age of $20.14 \pm 0.25 \mathrm{Ma}$ $(\mathrm{MSWD}=2.4, n=14)\left(\right.$ Table DR5 $\left.^{1}\right)$.

For sample GF13-10, zircon CL images show rare grains with distinct cores and rims. Only 3 cores were dated and give Palaeozoic dates. The remaining data points give Miocene dates. The most concordant data (Fig. 3E) define a concordia age of $20.18 \pm 0.18$ Ma $(\mathrm{MSWD}=1.9 ; n=18)$, in agreement with the mean ${ }^{206} \mathrm{~Pb} /{ }^{238} \mathrm{U}$ age of $20.08 \pm 0.20 \mathrm{Ma}$ $(\mathrm{MSWD}=2.6 ; n=23)\left(\right.$ Table DR6 $\left.{ }^{1}\right)$.

This article is protected by copyright. All rights reserved. 


\section{AGES OF EXTENSION AND THRUSTING IN SEMI-BRITTLE STRUCTURES}

Lower-crustal melting during thinning is coeval with upper-crustal shearing accommodated by $\mathrm{C}^{\prime}$-type extensional shear planes (Figs. 4A,B and structural details in Frasca et al., (2016)). ${ }^{40} \mathrm{Ar} /{ }^{39} \mathrm{Ar}$ step-heating analysis of the white micas along these $\mathrm{C}^{\prime}$-type shear planes (Sample B-1505, Fig. 4C) yields a discordant age spectrum due to the mixing of two generations of mica, with a young component dated around $20 \mathrm{Ma}$ and an older one of $24 \mathrm{Ma}$ or older. Therefore, the intermediate segment at $22.59 \pm 0.13 \mathrm{Ma}$ is meaningless (Fig. 4C). The riftrelated structures are then crosscut by thrust-related structures (thrusts and dextral strike-slip faults, see details in Frasca et al. (2015)). ${ }^{40} \mathrm{Ar} /{ }^{39} \mathrm{Ar}$ step-heating analysis of the white micas extracted from the matrix of the tectonic breccia (Sample B-1503, Fig. 4D) along one of the dextral strike-slip lateral ramps of the Ronda Peridotites Thrust (see stereoplot in Fig. 4B) gives a plateau age of $20.16 \pm 0.11 \mathrm{Ma}$ at the end of degassing, after the release of an excess argon component for $60 \%$ of ${ }^{39} \mathrm{Ar}$ (see the age spectrum in Fig. 4D, complete isotopic results in Table DR7 ${ }^{1}$ and method details in Table DR $1^{1}$ ). Note that the two generations of micas in sample B1505 (rift-related structure, Fig. 4C) may reflect these two stages of deformation, with the old ages at ca. 24 Ma related to rifting and the young ages at ca. 20 Ma related to thrusting.

\section{DISCUSSION AND CONCLUSION}

The coupling of geochronological and geochemical data with the regional structures allows us to identify and date two distinct tectonic events during the Lower Miocene, related to mantle exhumation and its final thrust emplacement: 1- lithospheric thinning in a backarc setting leading to in-situ melting at ca. 22.5 Ma, coherent with $\mathrm{C}^{\prime}$-type extensional shear bands in the mid/upper crust (Ar-Ar ages); and 2- rift-inversion marked by a hot thrusting of 
the Ronda Peridotites and the overlying crustal envelope onto the continental crust, dated at ca. 20 Ma by undeformed dikes cross-cutting the former HT foliation (in both the peridotites and the overlying high-grade crustal rocks) and by brittle thrust-related faults. The differences in geochemistry, age and structural setting unequivocally separate these two different crustal melting events (Fig. 5).

The new age of ca. 22.5 Ma for the rift-related structures is compatible with previous geochronological data attesting to Oligo-Miocene rifting in the Alboran Domain: $\mathrm{U}-\mathrm{Pb}$ ages of 22.0 $\pm 0.3 \mathrm{Ma}$ and $22.7 \pm 0.3 \mathrm{Ma}$, obtained on zircon rims from granulites (Platt et al., 2003a) in Ronda and Beni Bousera (Moroccan equivalent of the Ronda peridotites); LA-ICP-MS ages of $21.3 \pm 0.3 \mathrm{Ma}$ obtained on syn-foliation monazites within the granulites, and an ${ }^{40} \mathrm{Ar} /{ }^{39} \mathrm{Ar}$ biotite age of $22.5 \pm 0.5 \mathrm{Ma}$ from granulites overlying the Beni Bousera Peridotites (Gueydan et al., 2015; Michard et al., 2006).

The new ages of ca. 20 Ma for the dikes intruding the thinned lithosphere (GF13-5a, GF13-9 and GF13-10) are relatively younger than suggested by some previous U-Pb data (Fig. 5). The older ages of dikes intruding the peridotites $(21.5 \pm 3.8$ and $22.6 \pm 1.8 \mathrm{Ma}$; Esteban et al., 2011) suggest a possible onset of thrusting at 22-21 Ma, although the large errors affecting the concordia ages and the limited number of analyzed zircon grains do not permit precise dating. Zircon ages of $21.79 \pm 0.6$ (younger intersection on the concordia diagram) and $22.3 \pm 0.2 \mathrm{Ma}$ (weighted ${ }^{206} \mathrm{~Pb} /{ }^{238} \mathrm{U}$ mean age), reported from dikes in the thinned continental crust above the peridotites, have been interpreted as a metamorphic imprint on Hercynian partial melting products or as thrust-related intrusion (Sánchez-Navas et al., 2014; Rossetti et al., 2010). Ar-Ar data on biotites from undeformed granites (Monié et al., 1994; Sosson et al., 1998) and the Ar-Ar plateau age on white micas from thrust-related structures presented in this study support thrusting at 21-20 Ma. Finally, a major change in sedimentation in both the external and the internal domains at around $20 \mathrm{Ma}$ is interpreted as 
a marker of the onset of thrusting in the Western Betics (see review in Frasca et al. (2015)).

The compilation of available geochronological data for the Western Alboran domain (western Betics and Rif) shows a bimodal distribution of Ar-Ar ages on micas, zircon fission track (ZFT) and apatite fission track (AFT) ages, suggesting two distinct cooling events related to the two crustal-melting events reported here (Fig. 5, Table DR8 ${ }^{1}$ ). A first cooling event occurred between 25 and 22-20 Ma and may mark the late stage of continental rifting (Fig. 5, see discussion in Frasca et al. (2016)). However, the majority of ages using mediumto low-temperature thermochronometers are younger than $20 \mathrm{Ma}$ (Fig. 5). The absence of older ages in the thrust footwall (see ages in dark grey in Fig. 5; Monié et al., 1994; Esteban et al., 2013) supports a reset of these low-temperature thermochronometers during heating at ca. $21 \mathrm{Ma}$, as a consequence of the hot emplacement of the peridotites nappe on a colder crustal unit (Fig. 5), followed by a general fast cooling. The characteristic time for cooling $\left(t_{\mathrm{c}}\right)$ is controlled by the thickness of the thrust sheet (the Ronda Peridotites and their crustal envelope) and its thermal diffusivity, $t_{\mathrm{c}}=d^{2} / K$, where $K=10^{-6} \mathrm{~m}^{2} / \mathrm{s}$ (Turcotte and Schubert, 1982). Taking $10 \mathrm{~km}$ as an average thrust-sheet thickness yields a characteristic time of 3.17 Ma for the conductive cooling of the thrust sheet, explaining the regional fast cooling starting at ca. $21 \mathrm{Ma}$.

At the regional scale, the tectonic history of the Ronda Peridotites is the result, during slab rollback, of a fast switch at ca. 21 Ma from exhumation driven by back-arc extension (i.e. rifting) to a thrust emplacement of the overriding plate onto the Iberian margin. This sequence of events, from rifting between 30 and $21 \mathrm{Ma}$ to thrusting at ca. $21 \mathrm{Ma}$, is consistent with the geodynamic model of Duggen et al. (2004), based on geochemical tracers: subduction processes (marked by the Malaga tholeiite dikes) followed by nappe emplacement (marked by crustal melting). A remaining key issue is to identify the exact location of the rift inversion, either to the north of the Algerian margin or close to the present-day position of the 
Gibraltar arc. These two hypotheses would imply either a large (e.g., Hidas et al., 2013) or a limited (e.g., Frasca et al., 2015) amount of rollback since 20 Ma, respectively.

\section{Acknowledgements}

This work was funded by the European Union FP7 Marie Curie ITN “TOPOMOD”, contract 264517. Thanks to A. Delplanque and P. Frasca for help in drawing Fig. 5 and to Bernard Célérier for useful discussions. Very constructive comments made by David Chew, an anonymous reviewer, the Associate Editor and Editor helped to improve the manuscript.

\footnotetext{
${ }^{1}$ Supplementary material
}

Figure 1. (A) Tectonic map of the Ronda Peridotites massifs (from Frasca et al. 2015), showing the sampling locations in the Carratraca area. $\mathrm{A}$ and $\mathrm{A}^{\prime}$ are the endpoints of the cross-section line shown in (C). Inset: position of the Alboran Domain between the Nubia and Iberia plates, showing the locations of sub-continental mantle and of the studied area. RPT: Ronda Peridotites Thrust (blue); CMESZ: Crust-Mantle Extensional Shear Zone (red). (B) Tectonic map of the Beni Bousera peridotites massif (modified after Afiri et al., 2011). Colours are illustrated in the generalized vertical section at the top right of (A). (C) Simplified N-S regional cross-section. Note the strike-slip deformation zones that laterally accommodate the RPT motion. Stars and diamonds indicate the positions of the samples collected for $\mathrm{U}-\mathrm{Pb}$ and $\mathrm{Ar}-\mathrm{Ar}$ analyses, respectively (blue: rift-related sample; red: thrustrelated sample). 
Figure 2. (A) Schematic relationships (not to scale) between peridotites, overlying rocks and metamorphic sole, with structural positions of the samples selected for $\mathrm{U}-\mathrm{Pb}$ studies. (B) Melt vein rotated during progressive top-to-the-west shearing (evolution shown in the diagram). (C) Syn-kinematic leucocratic vein within $C^{\prime}$-type shear band in the deep crust. (D) Graphic texture between zoned tourmaline and quartz (GF13-7); plane-polarized light. (E) Stereoplot of foliations in the lower crust, with stretching lineations along the CMESZ and associated sense of shear (lower hemisphere; Schmidt net); data from the Sierras de Carratraca. (F) Stereoplot of the melt syn-kinematic veins in the lower crust (Carratraca area). (G) Undeformed granite intrusion in the peridotites. (H) Dike cross-cutting the regional foliation in the granulite of the lower crust. (I) Granophyric textures of different sizes testifying to the different phases of crystallization of K-feldspar-quartz intergrowths in a melt (GF13-5a); crossed-polarized light. (L) Stereoplot of the dikes and sills cutting through the peridotites and dikes cutting the regional foliation in the lower crust (Carratraca area). GPS locations of the sampled outcrops can be found in Table DR9 ${ }^{1}$.

Figure 3. (A) Different chondrite-normalized patterns for the collected samples and those of Rossetti et al. (2013). (B-E) Concordia diagrams for the time interval between ca. 25 and 18 Ma, showing LA-ICP-MS U-Pb zircon analyses for samples GF13-7, GF 13-5a, GF13-9 and GF13-10. Error ellipses are at $2 \sigma$. Plain back ellipses: analyses used for Concordia age calculations; dashed ellipses: data with common $\mathrm{Pb}$; light grey ellipses: data with slight $\mathrm{Pb}$ loss. Insets show CL pictures of some of the grains dated in this study together with the obtained ${ }^{206} \mathrm{~Pb} /{ }^{238} \mathrm{U}$ dates. Data tables are available in the supplementary material ${ }^{1}$.

Figure 4. (A) 3D visualization of the southeastern termination of the Carratraca massif, with the geological contours superposed on the topography from GoogleEarth@. Grey and red: 
rift-related La Robla normal fault and El Chenil Low Angle Normal Fault (LANF). Blue: riftinversion-related compressional and strike-slip faults (modified after Frasca et al., 2016). For location and details of colours see Fig. 1. GPS locations of the sampled outcrops can be found in Table DR9 ${ }^{1}$. (B) Stereoplots of data collected in the area of (A) (lower hemisphere; Schmidt net): foliations in the upper crustal rocks, stretching lineations and associated $\mathrm{C}^{\prime}-$ type shear bands with the arrow indicating the sense of shear (OSXStereonet: version 9.2.0. http://www.ux.uis.no/ nestor/work/programs.html); and rift-inversion-related fault surfaces (great circles) with slip vectors (blue arrows) (FSA software by Célérier (2013): version 35.2). (C,D) ${ }^{40} \mathrm{Ar} /{ }^{39} \mathrm{Ar}$ age spectra for white micas extracted from samples B-1503 (rift-related structure) and B-1505 (thrust-related structure; see method and analytical data in Tables DR1 and DR7 in "supplementary material"1).

Figure 5. Frequency distribution of the ages available for the western Betics, Rif, ODP Leg 161 and ages obtained in our study (symbols as in Fig. 1). The black line is the best approximation of the trend of the data (polynomial degree 7), excluding the extremity values. From top to bottom: i) U-Pb on zircons (Platt and Whitehouse, 1999; Sánchez-Rodríguez and Gebauer, 2000; Platt et al., 2003b; Esteban et al., 2007, 2011); ii) ${ }^{40} \mathrm{Ar} /{ }^{39} \mathrm{Ar}$ on micas (Chalouan et al., 2008; Monié et al., 1994; Kelley and Platt, 1999; Sosson et al., 1998; Platt et al., 2003a; Rossetti et al. 2010; Frasca et al., 2016); and iii) fission tracks on zircon (Platt et al., 2003a; Esteban et al., 2004, 2005, 2007; Azdimousa et al., 2013) and apatite (Hurford et al., 1999; Sosson et al., 1998; Platt et al., 2003a; Esteban et al., 2004, 2005; Azdimousa et al., 2013). Pale and dark grey colours in the histograms correspond to samples above and below the RPT, respectively. The bimodal distributions of Ar-Ar, ZFT and AFT ages are well correlated with the two Lower Miocene tectonic events (syn-rift in red and rift inversion in blue; see sketches on top).

This article is protected by copyright. All rights reserved. 
Table 1. Major, trace element and isotopic compositions of the melt products sampled in the Ronda Peridotites and their crustal envelope. ASI $=\mathrm{Al}_{2} \mathrm{O}_{3} /\left(\mathrm{Na}_{2} \mathrm{O}-1.67 \mathrm{P}_{2} \mathrm{O}_{5}+\mathrm{K}_{2} \mathrm{O}+\mathrm{CaO}\right)$, molar; $\mathrm{A} / \mathrm{NK}=\mathrm{Al}_{2} \mathrm{O}_{3} /\left(\mathrm{Na}_{2} \mathrm{O}+\mathrm{K}_{2} \mathrm{O}\right)$, molar; $\mathrm{A} / 2 \mathrm{CNK}=\mathrm{Al}_{2} \mathrm{O}_{3} /\left(\mathrm{CaO}+\mathrm{Na}_{2} \mathrm{O}+\mathrm{K}_{2} \mathrm{O}\right)$, molar.

\begin{tabular}{|c|c|c|c|}
\hline Sample & GF13-7 & GF13-6 & GF13-5A \\
\hline $\mathrm{SiO}_{2}$ (wt.\%) & 73.66 & 75.99 & 83.05 \\
\hline $\mathrm{TiO}_{2}$ & 0.14 & 0.06 & 0.09 \\
\hline $\mathrm{Al}_{2} \mathrm{O}_{3}$ & 14.00 & 13.24 & 8.19 \\
\hline FeOt & 1.81 & 0.68 & 0.72 \\
\hline $\mathrm{MnO}$ & 0.02 & 0.01 & 0.01 \\
\hline $\mathrm{MgO}$ & 0.36 & 0.48 & 0.18 \\
\hline $\mathrm{CaO}$ & 1.33 & 1.95 & 0.61 \\
\hline $\mathrm{Na}_{2} \mathrm{O}$ & 3.61 & 4.80 & 1.51 \\
\hline $\mathrm{K}_{2} \mathrm{O}$ & 2.64 & 0.74 & 4.31 \\
\hline $\mathrm{P}_{2} \mathrm{O}_{5}$ & 0.14 & 0.05 & 0.03 \\
\hline LOI & 1.57 & 0.87 & 0.93 \\
\hline Total & 99.28 & 98.87 & 99.63 \\
\hline ASI & 1.27 & 1.09 & 1.00 \\
\hline A/NK & 1.59 & 1.52 & 1.15 \\
\hline $\mathrm{A} / 2 \mathrm{CNK}$ & 1.03 & 0.84 & 0.87 \\
\hline $\mathrm{Be}(\mathrm{ppm})$ & $<1$ & 5 & 2 \\
\hline Sc & 7 & 6 & $<1$ \\
\hline V & 16 & 5 & 8 \\
\hline $\mathrm{Cr}$ & 120 & 190 & 150 \\
\hline Co & 4 & 3 & 2 \\
\hline $\mathrm{Ni}$ & $<20$ & $<20$ & $<20$ \\
\hline $\mathrm{Rb}$ & 96 & 20 & 144 \\
\hline $\mathrm{Sr}$ & 405 & 204 & 82 \\
\hline Y & 24 & 13 & 3 \\
\hline $\mathrm{Zr}$ & 66 & 42 & 41 \\
\hline $\mathrm{Nb}$ & 11 & 7 & 4 \\
\hline Sn & 8 & 5 & 2 \\
\hline Cs & 1.4 & $<0.5$ & 2 \\
\hline $\mathrm{Ba}$ & 407 & 878 & 271 \\
\hline La & 11.1 & 13.6 & 20.2 \\
\hline $\mathrm{Ce}$ & 22.8 & 27.1 & 42.6 \\
\hline $\mathrm{Pr}$ & 2.62 & 3.03 & 4.97 \\
\hline $\mathrm{Nd}$ & 9.7 & 10.2 & 18.2 \\
\hline $\mathrm{Sm}$ & 2.8 & 2.9 & 4.1 \\
\hline $\mathrm{Eu}$ & 1.03 & 0.85 & 0.78 \\
\hline $\mathrm{Gd}$ & 2.8 & 2.3 & 2 \\
\hline $\mathrm{Tb}$ & 0.6 & 0.4 & 0.2 \\
\hline Dy & 4.2 & 2.6 & 0.8 \\
\hline Ho & 0.9 & 0.5 & 0.1 \\
\hline $\mathrm{Er}$ & 2.6 & 1.3 & 0.3 \\
\hline Tm & 0.48 & 0.21 & 0.05 \\
\hline $\mathrm{Yb}$ & 3.9 & 1.3 & 0.2 \\
\hline Lu & 0.62 & 0.17 & 0.04 \\
\hline $\mathrm{Hf}$ & 1.9 & 1.8 & 1.5 \\
\hline Ta & 2.1 & 1.8 & 0.3 \\
\hline W & 13 & $<1$ & $<1$ \\
\hline TI & 0.3 & $<0.1$ & 0.5 \\
\hline $\mathrm{Pb}$ & 23 & 12 & 32 \\
\hline $\mathrm{Bi}$ & $<0.4$ & $<0.4$ & $<0.4$ \\
\hline Th & 3.4 & 5.8 & 12.2 \\
\hline & & 6.6 & 13.3 \\
\hline${ }^{87} \mathrm{Sr} /{ }^{86} \mathrm{Sr}$ (standard) & 0.718605 & 0.720831 & 0.719869 \\
\hline & 0.000013 & 0.000012 & 0.000012 \\
\hline${ }^{143} \mathrm{Nd} /{ }^{144} \mathrm{Nd}$ (standard) & 0.512026 & 0.512068 & 0.512140 \\
\hline $\pm 2 \sigma$ & 0.000005 & 0.000004 & 0.000006 \\
\hline${ }^{147} \mathrm{Sm} /{ }^{144} \mathrm{Nd}$ & 0.15528 & 0.14569 & 0.12805 \\
\hline$\varepsilon N d(t)$ & -11.26 & -10.99 & -9.54 \\
\hline
\end{tabular}

This article is protected by copyright. All rights reserved. 


\section{REFERENCES}

Acosta-Vigil, A., Barich, A., Bartoli, O., Garrido, C., Cesare, B., Remusat, L., Poli S., Raepsaet, C., 2016, The composition of nanogranitoids in migmatites overlying the Ronda peridotites (Betic Cordillera, S Spain): the anatectic history of a polymetamorphic basement. Contrib. Mineral. Petrol., v. 171, no. 24, p. 1-31.

Afiri, A., Gueydan, F., Pitra, P., Essai, A., and Précigout, J., 2011, Oligo-miocene exhumation of the Beni-Bousera peridotite through a lithosphere-scale extensional shear zone. Geodinamica Acta, v. 24, no. 1, p. 49-60.

Argles, T., Platt, J., and Waters, D., 1999, Attenuation and excision of a crustal section during extensional exhumation: the Carratraca massif, Betic Cordillera, southern Spain. Journal of the Geological Society, v. 156, no. 1, p. 149-162.

Azdimousa, A., Bourgois, J., Poupeau, G., Vázquez, M., Asebriy, L., Labrin, E., 2014, Fission track thermochronology of the Beni Bousera peridotite massif (Internal Rif, Morocco) and the exhumation of ultramafic rocks in the Gibraltar Arc. Arabian Journal of Geosciences, v.7, no. 5, p. 1993-2005.

Bache, F., Olivet, J.-L., Gorini, C., Aslanian, D., Labails, C., Rabineau, M., 2010, Evolution of rifted continental margins: The case of the Gulf of Lions (Western Mediterranean Basin). Earth and Planetary Science Letters, v. 292, p. 345-356.

Balanyá, J. C., García-Dueñas, V., Azañón, J. M., and Sánchez-Gómez, M., 1997, Alternating contractional and extensional events in the Alpujarride nappes of the Alboran domain (Betics, Gibraltar arc). Tectonics, v. 16, no. 2, p. 226-238.

Ballouard, C., Boulvais, P., Poujol, M., Gapais, D., Yamato, P., Tartèse, R., Cuney, M., 2015, Tectonic record, magmatic history and hydrothermal alteration in the Hercynian Guérande leucogranite, Armorican Massif, France. Lithos, v. 220-223, p. 1-22.

Barich A., Acosta-Vigil A., Garrido C.J., Cesare B., Tajčmanová L., and Bartoli O., 2014, 
Microstructures and petrology of melt inclusions in the anatectic sequence of Jubrique (Betic Cordillera, S Spain): Implications for crustal anatexis. Lithos, v. 206-207, p. 303-320.

Cuevas, J., Esteban, J., and Tubía, J., 2006, Tectonic implications of the granite dike swarm in the Ronda Peridotites (Betic Cordilleras, southern Spain). Journal of the Geological Society, v. 163, no. 4, p. 631-640.

Duggen, S., Hoernle, K., van den Bogaard, P., and Harris, C., 2004, Magmatic evolution of the Alboran region: The role of subduction in forming the Western Mediterranean and causing the Messinian salinity crisis. Earth and Planetary Science Letters, v. 218, no. 1-2, p. 91-108.

Esteban, J. J., Cuevas, J., Tubía, J., Sergeev, S., and Larionov, A., 2011, A revised Aquitanian age for the emplacement of the Ronda peridotites (Betic Cordilleras, southern Spain). Geological Magazine, v. 148, no. 1, p. 183-187.

Esteban, J. J., Tubía, J. M., Cuevas, J., Seward, D., Larionov, A., Sergeev, S., and NavarroVilá, F., 2013, Insights into extensional events in the Betic Cordilleras, southern Spain: New fission-track and U-Pb SHRIMP analyses. Tectonophysics, v. 603, p. 179-188.

Esteban, J. J., Cuevas, J., Tubía, J. M., Gil Ibarguchi, J. I., and Seward, D., 2005, Metamorfismo, exhumación y termocronología de la Unidad de Yunquera (Alpujárrides occidentales, Cordilleras Béticas). Revista de la Sociedad Geológica de España, v. 18, no. 1-2, p. 61-74.

Esteban, J. J., Cuevas, J., Tubía, J.M., Liati, A., Seward, D., Gebauer, D., 2007, Timing and origin of zircon-bearing chlorite schists in the Ronda peridotites (Betic Cordilleras, Southern Spain). Lithos, v. 99, p. 121-135.

Frasca, G., Gueydan, F., and Brun, J.-P., 2015, Structural record of Lower Miocene westward Alboran Domain motion in the Western Betics (southern Spain). Tectonophysics, v. 657, p. $1-20$. 
Frasca, G., Gueydan, F., Brun, J.-P., Monié, P., 2016, Deformation mechanisms in a continental rift up to mantle exhumation. Field evidence from the western Betics, Spain. Marine and Petroleum Geology, v. 76, p. 1-19.

Garrido, C. J., Gueydan, F., Booth-Rea, G., Précigout, J., Hidas, K., Padrón-Navarta, J. A., and Marchesi, C., 2011, Garnet lherzolite and garnet-spinel mylonite in the Ronda peridotite: Vestiges of Oligocene backarc mantle lithospheric extension in the Western Mediterranean. Geology, v. 39, no. 10, p. 927-930.

Gueydan, F., Pitra P., Afiri, A., Poujol, M., Essaifi, A., and Paquette, J.-L, 2015, OligoMiocene thinning of the Beni Bousera peridotites and their Variscan crustal host rocks, Internal Rif, Morocco. Tectonics, 34, doi: 10.1002/2014TC003769.

Hidas, K., Booth-Rea, G., Garrido, C. J., Martínez-Martínez, J. M., Padrón-Navarta, J. A., Konc, Z., Giaconia, F., Frets, E., and Marchesi, C., 2013, Backarc basin inversion and subcontinental mantle emplacement in the crust: kilometre-scale folding and shearing at the base of the proto-Alborán lithospheric mantle (Betic Cordillera, southern Spain). Journal of the Geological Society, v. 170, no. 1, p. 47-55.

Hurford, A. J., Platt, J. P., and Carter, A., 1999, Fission-track analysis of samples from the Alboran Sea basement. In Zahn, R., Comas, M. C. and Klaus, A., editors. Proceedings of the Ocean Drilling Program, Scientific Results, v. 161, no. 21, p. 295-300.

Kelley, S.P., and Platt, J.P., 1999, Ar-ar dating of biotite and muscovite from Alboran basement samples. In Zahn, R., Comas, M. C., and Klaus, A., editors. Proceedings of the Ocean Drilling Program, Scientific Results, v. 161, no. 22, p. 301-305.

Lundeen, M., 1978, Emplacement of the Ronda Peridotite, Sierra Bermeja, Spain. Geological Society of America Bulletin, v. 89, p. 172-180.

Marchesi, C., Garrido, C. J., Bosch, D., Bodinier, J.-L., Hidas, K., Padrón-Navarta, J.A., and Gervilla, F., 2012, A Late Oligocene Suprasubduction Setting in the Westernmost 
Mediterranean Revealed by Intrusive Pyroxenite Dikes in the Ronda Peridotite (southern Spain). The Journal of Geology, v. 120, no. 2, p. 237-247.

Massonne H.-J., 2014, Wealth of P-T-t information in medium-high grade metapelites: Example from the Jubrique Unit of the Betic Cordillera, S Spain. Lithos, v. 208-209, p. 137157.

Chalouan, A., Michard, A., El Kadiri, K., Frizon de Lamotte, D., Negro, F., Soto, J., and Saddiqi, O., 2008, The Rif belt. In Michard, A., Saddiqi, O., Chalouan, A., de Lamotte, D.F., editors. Continental Evolution: The Geology of Morocco: Structure, Stratigraphy, and Tectonics of the Africa-Atlantic-Mediterranean Triple Junction. Springer, p. 203-302.

Mazzoli, S., and Martín-Algarra, A., 2011, Deformation partitioning during transpressional emplacement of a 'mantle extrusion wedge': the Ronda peridotites, Western Betic Cordillera, Spain. Journal of the Geological Society of London, v. 168, p. 373-382.

Monié, P., Torres-Roldán, R., and García-Casco, A., 1994, Cooling and exhumation of the Western Betic Cordillera, ${ }^{40} \mathrm{Ar} /{ }^{39} \mathrm{Ar}$ thermochronological constraints on a collapsed terrane. Tectonophysics, v. 238, no. 1-4, p. 353-379.

Negro, F., Beyssac, O., Goffé, B., Saddiqi, O., and Bouybaouéne, M. L., 2006, Thermal structure of the Alboran Domain in the Rif (northern Morocco) and the Western Betics (southern Spain). Constraints from Raman spectroscopy of carbonaceous material. Journal of Metamorphic Geology, v. 24, no. 4, p. 309-327.

Platt, J. P., and Whitehouse, M., 1999, Early Miocene high-temperature metamorphism and rapid exhumation in the Betic Cordillera (Spain): evidence from U-Pb zircon ages. Earth and Planetary Science Letters, v. 171, no. 4, p. 591-605.

Platt, J. P., Argles, T., Carter, A., Kelley, S., Whitehouse, M., and Lonergan, L., 2003a, Exhumation of the Ronda peridotite and its crustal envelope: constraints from thermal modelling of a P-T-time array. Journal of the Geological Society, v.160, no. 5, p. 655-676.

This article is protected by copyright. All rights reserved. 
Platt, J. P., Whitehouse, M., Kelley, S., Carter, A., and Hollick, L., 2003b, Simultaneous extensional exhumation across the Alboran Basin: implications for the causes of late orogenic extension. Geology, v. 31, no. 3, p. 251-254.

Précigout, J., Gueydan, F., Garrido, C. J., Cogné, N., and Booth-Rea, G., 2013, Deformation and exhumation of the Ronda Peridotite (Spain). Tectonics, v. 32, no. 4, p. 1011-1025.

Rossetti, F., Dini, A., Lucci, F., Bouybaouenne, M., and Faccenna, C., 2013, Early Miocene strike-slip tectonics and granite emplacement in the Alboran Domain (Rif chain, Morocco): significance for the geodynamic evolution of Western Mediterranean. Tectonophysics, v. 608, p. 774-791.

Rossetti, F., Theye, T., Lucci, F., Bouybaouenne, M., Dini, A., Gerdes, A., Phillips, D., and Cozzupoli, D., 2010, Timing and modes of granite magmatism in the core of the Alboran Domain, Rif chain, northern Morocco: Implications for the alpine evolution of Western Mediterranean. Tectonics, v. 29, TC2017.

Ruiz Cruz, M. D., and Sanz de Galdeano, C., 2014, Garnet variety and zircon ages in UHP meta-sedimentary rocks from the Jubrique Zone (Alpujárride complex, Betic Cordillera, Spain): evidence for a pre-alpine emplacement of the Ronda Peridotites. International Geology Review, v. 56, no. 7, p. 845-868.

Sánchez-Navas, A., García-Casco, A. and Martín-Algarra, A., 2014, Pre-Alpine discordant granitic dikes in the metamorphic core of the Betic Cordillera: tectonic implications. Terra Nova, v. 26, no. 6, p. 477-486.

Sánchez-Rodríguez, L., and Gebauer, D., 2000, Mesozoic formation of pyroxenites and gabbros in the Ronda area (southern Spain), followed by Early Miocene subduction metamorphism and emplacement into the middle crust: $\mathrm{U}-\mathrm{Pb}$ sensitive high-resolution ion microprobe dating of zircon. Tectonophysics, v. 316, no. 1-2, p. 19-44.

Serrano, F., Guerra-Merchán, A., Kadiri, K.E., Sanz de Galdeano, C., López-Garrido, A.C., 
Martín-Martín, M. and Hlila, R., 2007, Tectono-sedimentary setting of the Oligocene- Early Miocene deposits on the Betic-Rifian Internal Zone (Spain and Morocco). Geobios, v. 40, no. 2, p. 191-205.

Sosson, M., Morrillon, A.-C., Bourgois, J., Féraud, G., Poupeau, G., and Saint-Marc, P., 1998, Late exhumation stages of the Alpujarride complex (western Betic Cordilleras, Spain): new thermochronological and structural data on Los Reales and Ojen nappes. Tectonophysics, v. 285, no. 3-4, p. 253-273.

Tubía, J., Cuevas, J., and Ibarguchi, J. G., 1997, Sequential development of the metamorphic aureole beneath the Ronda Peridotites and its bearing on the tectonic evolution of the Betic Cordillera. Tectonophysics, v. 279, no. 1, p. 227-252.

Turcotte, D. L., and Schubert, G., 1982, Geodynamics: Applications of continuum physics to geological problems. John Wiley Ed., New York, p. 1-450.

Van Hinsbergen, D. J. J., Vissers, R. L. M., and Spakman, W., 2014, Origin and consequences of Western Mediterranean subduction, rollback, and slab segmentation. Tectonics, v. 33, no. 4, p. 393-419.

Villaseñor, A., Chevrot, S., Harnafi, M., Gallart, J., Pazos, A., Serrano, I., Córdoba, D., Pulgar, J. A., and Ibarra, P., 2015, Subduction and volcanism in the Iberia-North Africa collision zone from tomographic images of the upper mantle. Tectonophysics, v. 663, p. 238249.

Vitale, S., Zaghloul, M. N., Tramparulo, F. D., and Ouaragli, B. E., 2014, Deformation characterization of a regional thrust zone in the northern Rif (Chefchaouen, Morocco). Journal of Geodynamics, v. 77, p. 22-38.

Whitehouse, M., and Platt, J., 2003, Dating high-grade metamorphism - constraints from rare-earth elements in zircon and garnet. Contributions to Mineralogy and Petrology, v. 145, no. 1, p. 61-74.

This article is protected by copyright. All rights reserved. 
Wortel, M. J. R., and Spakman, W., 2000, Subduction and slab detachment in the

Mediterranean-Carpathian region. Science, v. 209, p. 1910-1917.

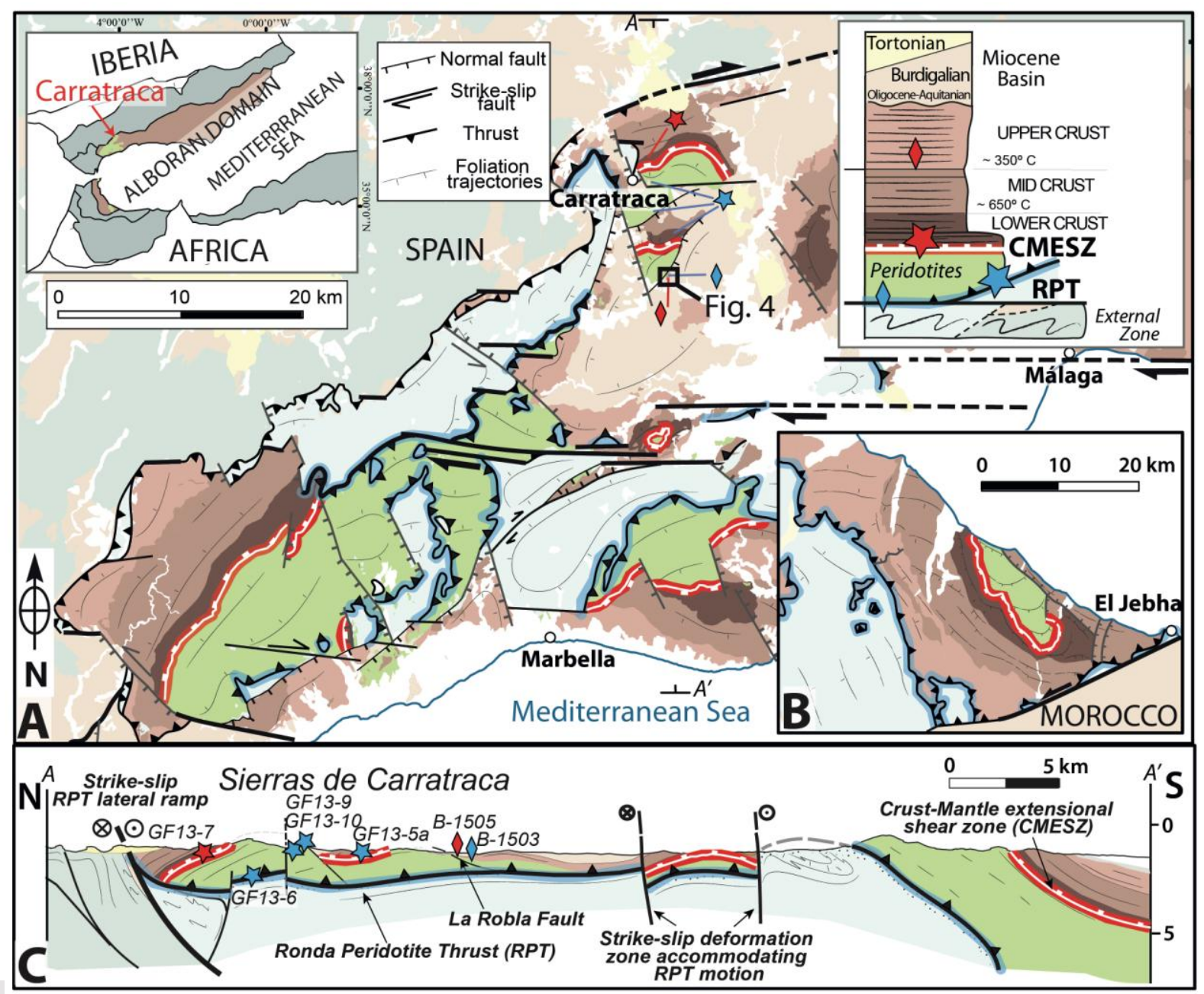

This article is protected by copyright. All rights reserved. 

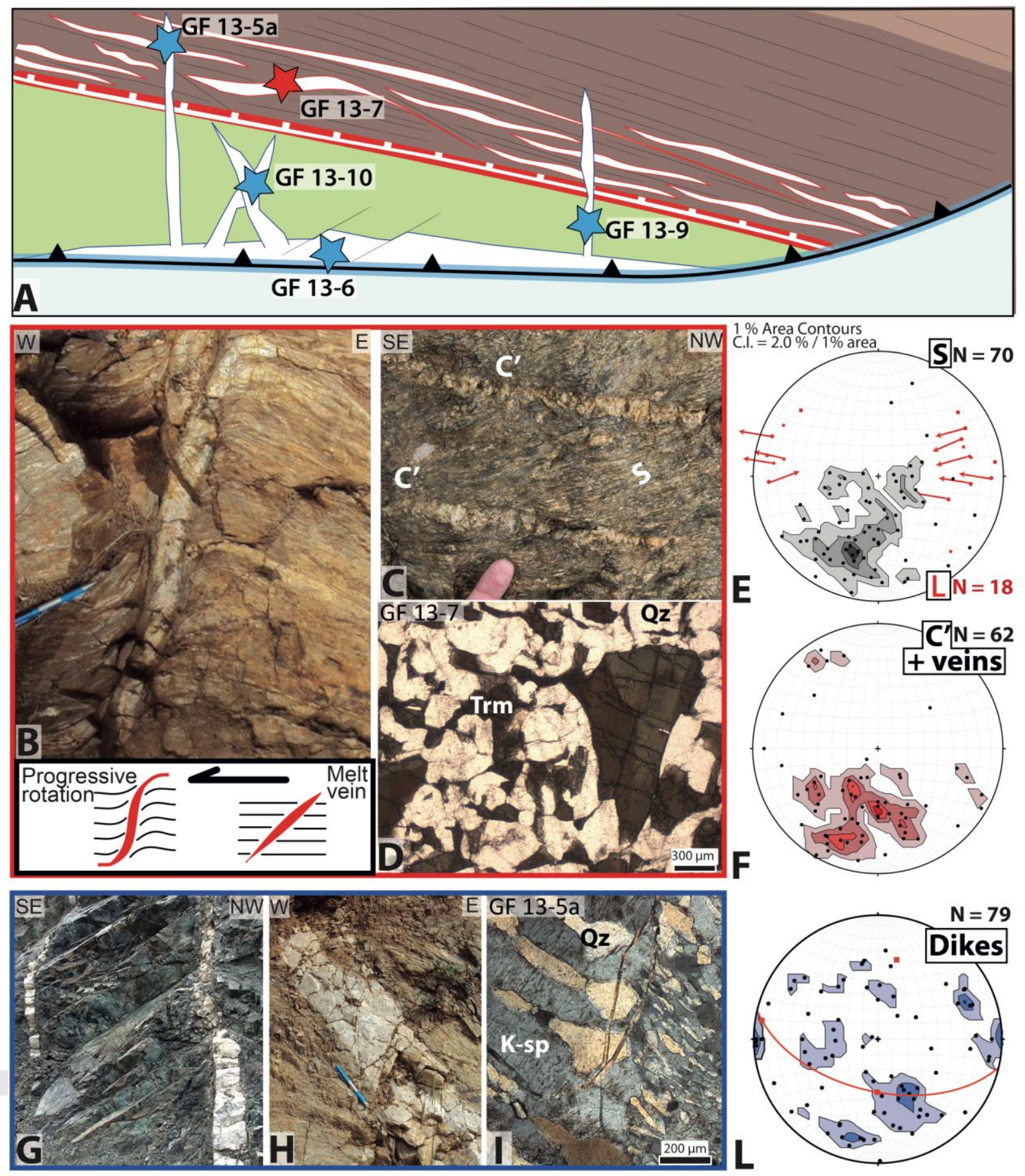

This article is protected by copyright. All rights reserved. 

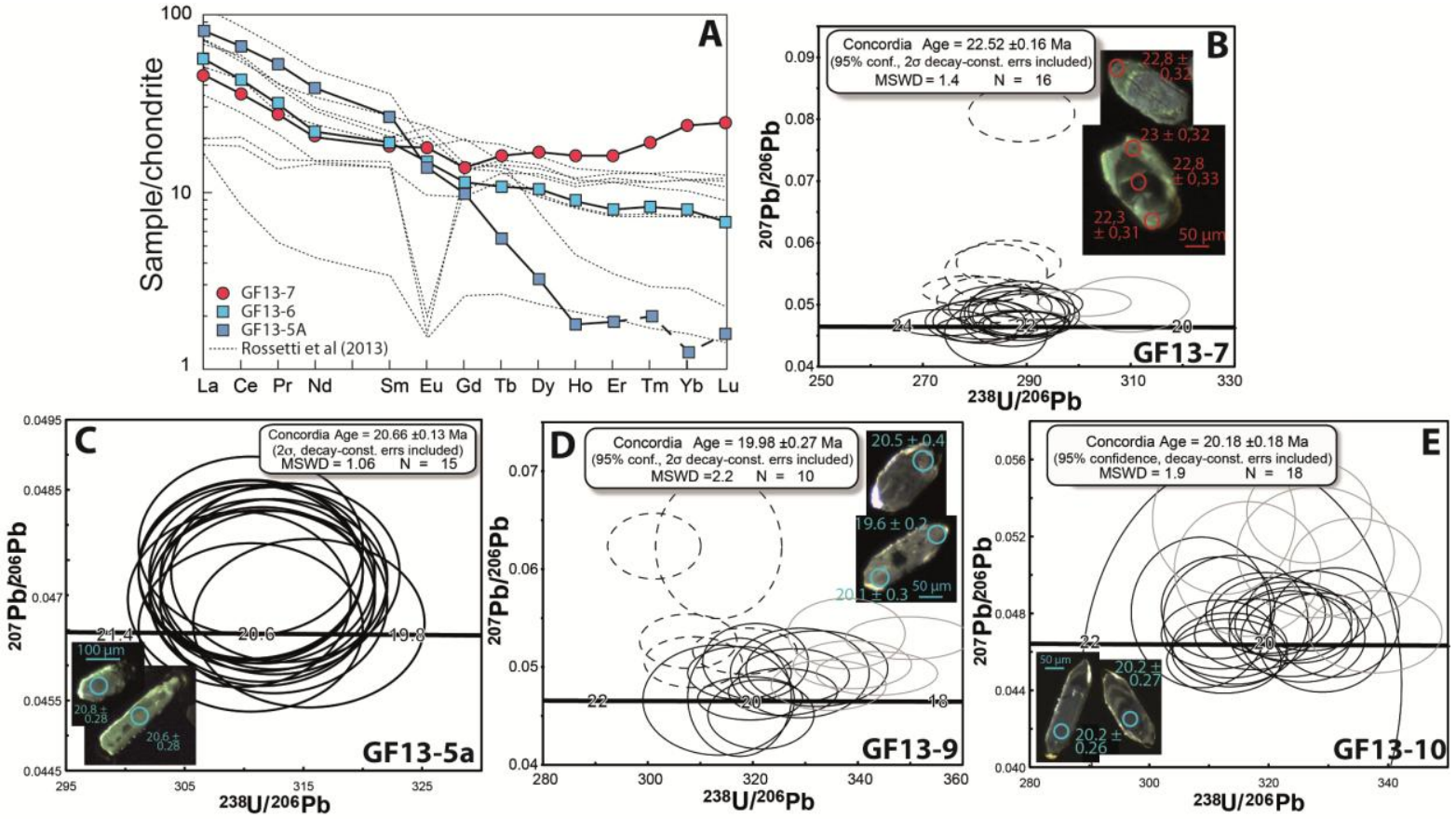

This article is protected by copyright. All rights reserved. 

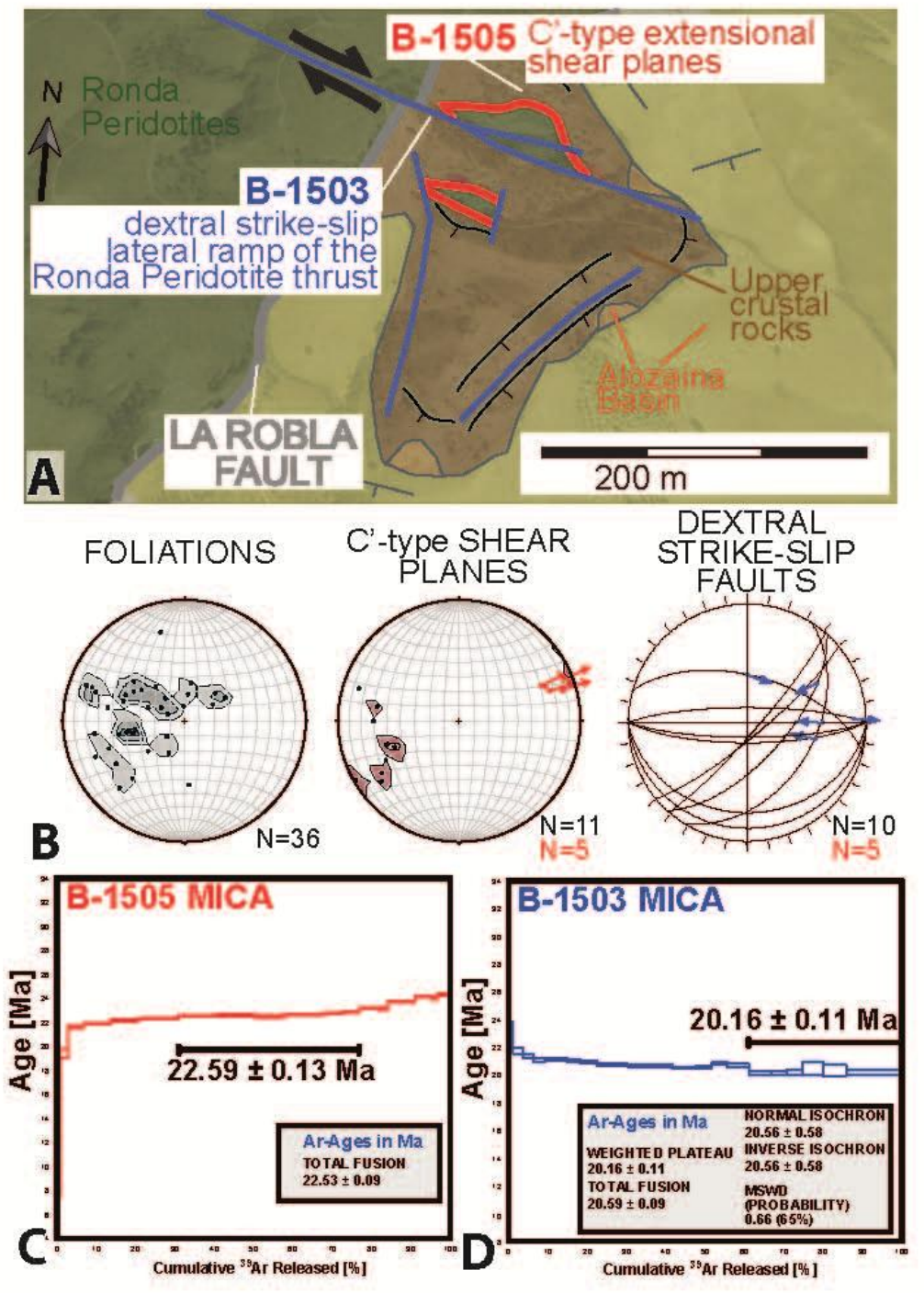

This article is protected by copyright. All rights reserved. 

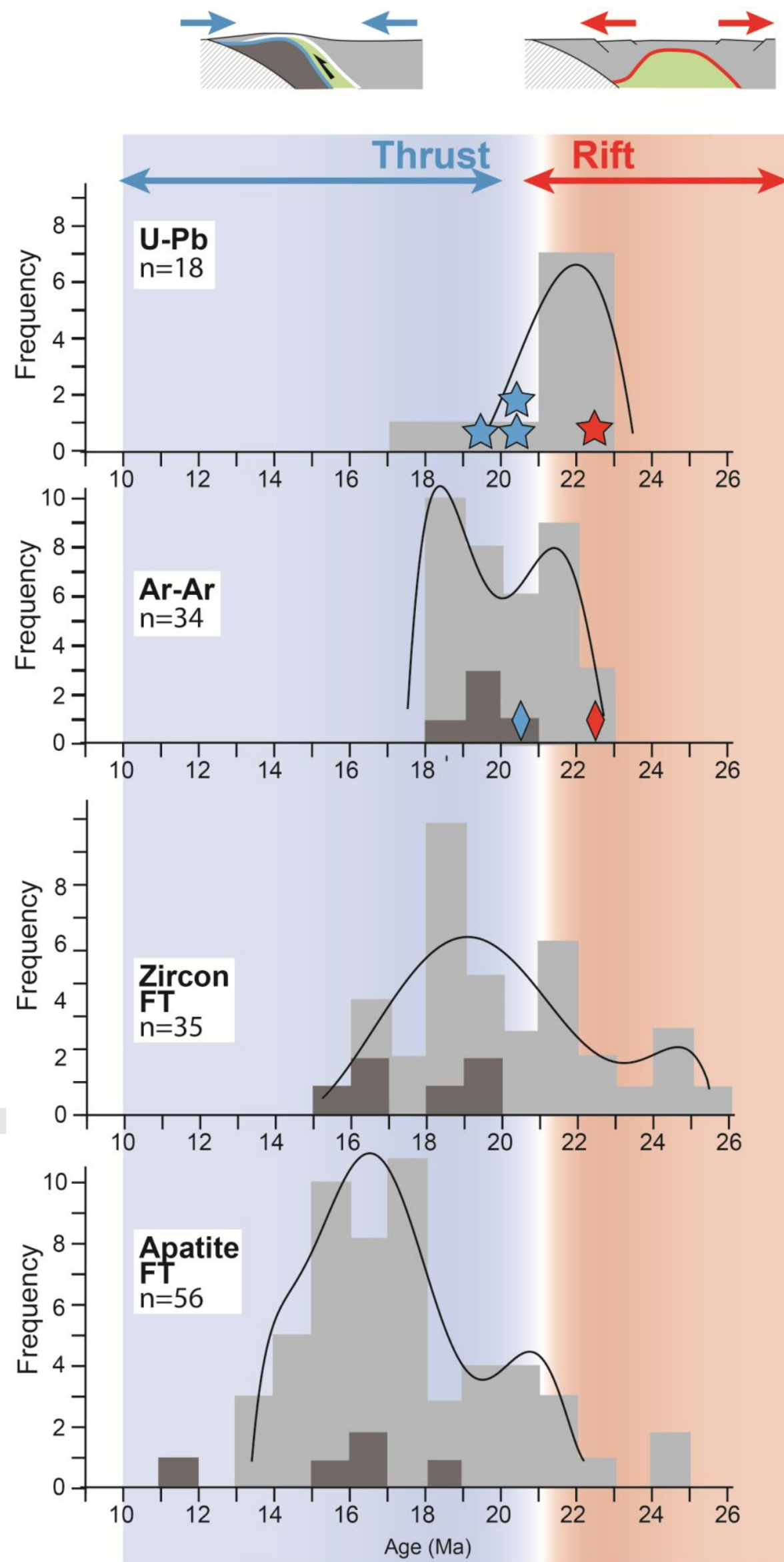

This article is protected by copyright. All rights reserved. 